\title{
Otoklavsız Gazbeton Kâgir Blok Elemanlarının Üretiminde Endüstriyel Atık Liflerin Kullanımı Üzerine Teknik Bir Analiz
}

\author{
Şeyma Pınar Özcan ${ }^{1 *}$, Lütfullah Gündüz ${ }^{2}$ \\ 1* İzmir Kâtip Çelebi Üniversitesi, Mühendislik Fakültesi, İnşaat Mühendisliği Bölümü, İzmir, Türkiye, (ORCID: 0000-0002-1395-196X), \\ seymapinarozcan@gmail.com \\ 2 İzmir Kâtip Çelebi Üniversitesi, Mühendislik Fakültesi, İnşaat Mühendisliği Bölümü, İzmir, Türkiye (ORCID: 0000-0003-2487-467X), \\ lutfullah.gunduz@ikc.edu.tr
}

(2nd International Conference on Access to Recent Advances in Engineering and Digitalization (ARACONF)-10-12 March 2021)

(DOI: $10.31590 /$ ejosat.900083)

ATIF/REFERENCE: Özcan, Ş.P., Gündüz, L. (2021). Otoklavsız Gazbeton Kâgir Blok Elemanlarının Üretiminde Endüstriyel Atık Liflerin Kullanımı Üzerine Teknik Bir Analiz. European Journal of Science and Technology, (24), 202-212.

$\ddot{\mathbf{O} z}$

Taşıyıcı özellikte olmayan hafif yapı malzemelerinin gelişimde son yıllarda giderek önem kazanan ve yaygınlaştığı görülen ürün türevleri arasında otoklavsız gazbeton kâgir blok elemanlarının varlığı dikkat çekmektedir. Gerek birim ağırlıklarının düşük oluşu, gözenekli yapısı, uygulama kolaylığı ve gerekse yalıtım özellikleri gibi teknik avantajları sebebiyle özellikle taşıyıcı olmayan yapı birimlerinde giderek tercih edildiği de görülebilmektedir. Otoklavsız gazbeton kâgir blok elemanları birçok farklı malzeme kullanımları ile yapılabilmekte olup, özellikle bileşiminde farklı uzunluk ve orijinlerde lif katkı malzemelerinin matris donatı materyali olarak kullanımı endüstriyel atıkların geri kazanımı açısından ayrı bir önem kazanmaktadır.

$\mathrm{Bu}$ bildiride, endüstriyel atık lif kategorisinde değerlendirilebilen 3 farklı lif türünün matris yapıdaki donatı etkisi üzerine sürdürülmekte olan deneysel bir ArGe çalışmasının ön bulguları teknik olarak tartışılmaktadır. Bu araştırma çalışması lif katkılarının kullanıldığı otoklavsız ön kürlemeli, genleştirilerek elde edilen kâgir blok elemanlarının üretimine yöneliktir. Bu lif türlerinden ikisi, kot kumaşının geri dönüşümünde kot elyaf açma işleminden geçirilerek elde edilmiş lif malzemeleridir. Bu çalışmada Lif 1 ve Lif 2 olarak kodlanmıştır. Lif 1 olarak kodlanmış elyaf türü, 90/10 pamuk/sentetik oranına sahiptir. Maksimum lif boyutu 3 mm'dir. Lif 2 olarak kodlanmış elyaf türünde ise 70/30 pamuk/sentetik oranına sahiptir. Ayrıca bu lif malzemenin maksimum lif boyutu ise 2 mm'dir. Lif 3 olarak kodlanmış lif, endüstriyel kâğıt atıklarının geri dönüşümünden elde edilmiş ve ortalama lif uzunluğu $\sim 200 \mu \mathrm{m}$ olan orta büyüklükte, \% 100 doğal, yüksek oranda saf selüloz beyaz renkli bir elyaftır.

Bu çalışmada, özellikle endüstriyel lif atıklarının farklı kullanım oranlarında hazırlanan harç örneklerinde, lif kullanımın etkileri ve lif uygunluğu incelenmektedir. Elde edilen bulgulara dayanılarak, karışımlarda kullanılan malzeme tür ve miktarlarının otoklavsız gazbeton blok elemanı örneklerinin teknik özelliklerine olan etkileri detaylı analiz edilmektedir. Yeni nesil yapı elemanı örneklerinin birim ağırlık, basınç dayanımı, kütlece su emme, gözeneklilik ve ısısal konfor özellikleri gibi fiziksel ve mekanik özellikleri bu bildiride endüstriyel yaklaşımlarıyla tartışılmaktadır.

Anahtar Kelimeler: Endüstriyel Atık Lif, Donatı, Otoklavsız Gazbeton, Kâgir Blok, Genleşme.

\section{A Technical Analysis on the Use of Industrial Waste Fibers in the Production of Non-Autoclaved Aerated Concrete Masonry Block Elements}

\begin{abstract}
The presence of non-autoclaved aerated concrete masonry block elements in recent years is among the product derivatives that have become increasingly important and widespread in the development of lightweight construction materials. It can be seen that it is increasingly preferred especially in non-load bearing building units due to its low unit weights, porous structure and ease of application and technical advantages such as insulation properties. Non-autoclaved aerated concrete masonry block elements can be
\end{abstract}

* Sorumlu Yazar: seymapinarozcan@gmail.com 
made with the use of many different materials, especially the use of fiber additives of different lengths and origins as matrix reinforcement materials gains a special importance in terms of recovery of industrial wastes.

In this paper, preliminary findings of an ongoing experimental research and development study on the reinforcement effect in matrix structure of 3 different fiber types that can be considered in the industrial waste fiber category are technically discussed. This research study focuses on the production of non- autoclaved pre-cured, expanded masonry block elements using fiber additives. Two of these fiber types are fiber materials obtained from the recycling of denim fabric by opening denim fiber. In this study, these fibers are coded as Fiber 1 and Fiber 2. The fiber type, coded as fiber 1, has a cotton/synthetic ratio of 90/10. Its maximum fiber length is 3 mm. In the fiber type coded as fiber 2, it has a ratio of 70/30 cotton/ synthetic. In addition, the maximum fiber length of this fiber material is 2 $\mathrm{mm}$. The fiber, coded as Fiber 3, is a medium-sized, $100 \%$ natural, highly pure cellulose white fiber with an average fiber length of $\sim 200 \mu \mathrm{m}$, obtained from recycling industrial paper waste.

In this study, the effects of different fiber usage rates and fiber suitability are examined on non-autoclaved aerated concrete masonry mortar samples prepared with industrial different fiber wastes. Based on the findings, the effects of the types and amounts of materials used in the mixtures on the technical properties of non-autoclaved aerated concrete block element samples are analyzed in detail. The physical and mechanical properties of the new generation building element samples such as unit weight, compressive strength, water absorption by mass, porosity and thermal comfort properties are discussed in this paper with industrial approaches.

Keywords: Industrial Waste Fiber, Reinforcement, Non-Autoclaved Aerated Concrete, Masonry Block, Expansion.

\section{Giriş}

Günümüz inşaat endüstrisinin en önemli hususlarının başında binalarda enerji verimliliği ve isısal konfor açısından yalıtım performansı gelmektedir. Bulundukları iklim bölgelerine göre binalarda 1sisal konforun sağlanması amaciyla bina projelendirmelerinde yap1 malzemeleri ile ilgili uyulması gereken yönetmelik ve standartlar söz konusudur. Projelerde yalıtım performansı binanın tasarımı ile doğrudan ilgili olduğu kadar, binanın yapımında kullanılan yap1 malzemelerinin türevleri, 1sısal özellikleriyle de kaçınılmaz doğrudan ilgilidir. Bu bağlamda, bir dizi teknik incelemelerin yapılması öngörülen mukavemet değerlerini sağlamak koşuluyla genellikle yap1 elemanlarının yalıtım performansının iyileştirilmesi açısından önem arz etmektedir. Günümüze değin yapıla gelen ağırlıklı teknik incelemelerde, bir binanın yalıtım performansının, dış bölme duvarları oluşturan yapı malzeme türevleri ve duvar kesit bileşenlerinin değerleri ile doğrudan etkili olduğu görülmüştür. $\mathrm{Bu}$ bağlamda, duvarlarda ısı yalıtımı amacıyla da sıç̧a tercih edilen hafif yapı elemanı kâgir bloklar, özellikle son yaşanan doğal afetler dolayısıyla bina ölü yük dengesinin oluşturulmasında önemli bir unsur olarak kabul görmektedir. Kentsel binaların artık daha yüksek inşa edilmesinden bina ölü yüklerinin azaltılmasına ihtiyaç duyulmaktadır. (Chen vd. 2017).

$\mathrm{Bu}$ kâgir blok elemanları hafif agrega türevlerinin kullanımıyla üretilebildiği gibi, çeşitli genleştirici ajanların kullanımıyla da gözenek oluşturulmasına bağlı gazbeton blok üretimlerine olanak sağladığı bilinen bir gerçektir. Ancak, günümüzde kâgir elemanların üretimlerinde giderek önemsenen bir husus ise minimum enerji tüketimi ile bu ürünlerin gerçekleştirilmesidir. Genleştirici ajan kullanımıyla üretimleri sürdürülmekte olan çoğu yapı elemanlarının üretiminde otoklav kürlemesi uygulanmakta olup, bu da üretimde yüksek enerji sarfiyatını gündeme getirmektedir. Bu olguyu minimize etmek amaciyla otoklav kullanmaksızın benzer teknik performansları sağlayabilen yapı malzeme ürünlerinin minimum enerji tüketimiyle üretilebilirliğinin geliştirilmesi günümüz ekonomisi açısından da son derece önemlidir. Bu üretimlerde, otoklavsız gazbeton harcının genleşme sürecinde matris yapısının desteklenmesi amacıyla alternatif lif materyallerinin kullanımı ve uygunluğunun belirlenmesi de ayrıca üzerinde araştırma gerektiren bir durumdur. Günümüzde, bu uygulamaların mevcutlarına göre yeni nesil olarak da nitelendirilebilecek yenilikçi versiyonlarına ihtiyaç duyulmaktadır.
Son zamanlarda, inşaat endüstrisinde, enerji ve hammadde tüketimini azaltmayı ve inşaatın kalitesini ve güvenilirliğini artırmayı amaçlayan bir dizi yeni düzenleyici faaliyetler önem kazanmaktadır. Otoklavlanmamış gazbetonun yaygın kullanımı, birçok ülkede dış bina zarflarının termal özelliklerini artırmanın yollarından biri olarak kabul görmektedir. Otoklavlanmayan gazbeton alanındaki araştırma ve uygulamaların amacı, ürün maliyetini düşürürken ürün kalitesini de iyileştirmektir. Genel olarak yap1 malzemeleri teknolojisi ve özellikle gazbeton teknolojisi için endüstriyel atığın kullanılması, temel malzeme özelliklerinin iyileştirilmesine, teknik ve ekonomik performansın artırılmasına olanak tanıdığından; aynı zamanda endüstriyel atıkların geri dönüşümü nedeniyle çevre ekolojisini de iyileştirecektir (Sanytsky, 2010).

Hafif beton, büyük ilgi uyandıran çok yönlü bir malzeme olarak kabul edilir ve son yıllarda yüksek yapılar ve köprüler gibi çok çeşitli inşaat projelerinde büyük endüstriyel talep görmektedir. Geleneksel normal agregalı betondan daha hafiftir (El Zareef, 2010; Babu, 2008). Gazbeton, çeşitli avantajları olan hafif bir beton türüdür. Hafif betonlar, normal betonlara kıyasla daha düşük birim ağırlığa ve dayanıma sahip, 1sı ve ses yalıtım değerleri yüksek, kolay çivilenebilme ve kolay kesilebilme gibi işlenebilme özellikleri olan, ateşe karşı daha dayanıklı bir yapı malzemesidir (Spratt, 1975). Çimento ve kireç, silis kumu ve bazen puzolanik malzemelerden oluşan harç matrisine hava boşluklarının hapsedildiği gazbeton, yoğunluğu sebebiyle hafif beton olarak sınıflandırılır. Gözenek oluşturma yöntemine göre üç gruba ayrılır: hava sürükleme yöntemi (gazbeton), köpürtme yöntemi (köpüklü beton) ve kombine yöntem. Gazbeton, kürleme yöntemine göre otoklavlanmamış veya otoklavlanmış olabilir. Basınç dayanımı, kuruma büzülmesi, su emme özellikleri vb. doğrudan kürleme yöntemine ve süresine bağlıdır. Yeterince sertleştikten sonra beton köpüğü kalıbından çıkarılır, gerekli boyutta bloklar veya levhalar halinde dilimlenir (Tanacan vd., 2009).

Gazbeton harcı karışımlarında farklı orijinlerde lif katkıları donatı materyali olarak kullanılabilmektedir. $\mathrm{Bu}$ lifler, doğal orijinli olabildikleri gibi yapay orijinli malzemeler de olabilmektedir. Lif kullanımının gazbetonun teknik özelliklerini iyileştirici etkileri çoğu araştırmacılar tarafindan uzun dönemlerdir rapor edilmektedir (Mobasher ve Li, 1996; PerezPena ve Mobasher, 1994; Bonakdar vd., 2013; Rasheed ve Prakash, 2017; Vijayalakshmi ve Ramanagopal, 2020a; Vijayalakshmi ve Ramanagopal, 2020b; Rasheed ve Prakash, 2015; Sukmana vd., 2019). Ancak bu liflerin orijinleri ve malzeme yapıları gereği, otoklavlama işlemi yapılması 
durumunda maruz kaldıkları yüksek sıcaklık ve basınçla bozunuma uğrayarak, lif katkısından beklenilen teknik performans sağlanamayabilmektedir. Özellikle sentetik kökenli liflerin yüksek sıcaklığa dayanıklı olmayışı, ayrıca doğal liflerin yüksek sıcaklık yanı sıra yüksek basınç ortamında hızla deformasyona uğrayabilmesi, normal koşullarda otoklavlı gazbeton üretimlerinde uygun görülmemektedir. Bu bağlamda, otoklav kullanımının lif katkılarının yapısal özelliklerinin bozunumu üzerindeki bu gibi olumsuz etkilerini de gidermek amacıyla otoklavsız gazbeton üretimlerinde lif katkılarının daha efektif kullanımlarını mümkün kılmaktadır. Örneğin polimerik lifler de otoklavsız gazbeton üretimlerinde kullanılabilmektedir. Polimerik liflerin otoklavsız gazbeton üretiminde kullanımında otoklavlama işleminde yer alan yüksek sıcaklık ve basınç işlevinin ortadan kaldırılması, lif formlarının olası bozunumlarını engelleyebilmektedir. Ayrıca, otoklavlanmış gazbetona kıyasla daha düşük mukavemet değerleri ve daha yüksek homojenlik oluşturmayabilir. Bununla birlikte, kısa lifler, plastik aşamada veya daha sonra mekanik kuvvetler, kuruma büzülmesi veya 1sitma-soğutma döngüleri nedeniyle oluşan çatlakların köprülenmesinde olumlu bir etkiye sahip olabilmektedir. Farklı araştırmacılar farklı zamanlarda yapmış oldukları çalışmalarda normal harç karışımlarına kısa polipropilen liflerinin eklenmesinin mekanik özellikleri büyük ölçüde iyileştirebileceğini, kısa liflerin ilave edilmesinin plastik fazda veya daha sonra kururken elastik fazda büzülme çatlaklarının azaldığını da rapor etmişlerdir (Bakhshi ve Mobasher, 2011; Ronald ve Carol, 1998).

$\mathrm{Bu}$ bildiride, endüstriyel lif atıklarının matris yapıda donatı katkısı olarak kullanıldığı otoklavsız ön kürlemeli, genleştirilerek elde edilen kâgir blok elemanlarının üretimine yönelik sürdürülmekte olan deneysel bir ArGe çalışmasının ön bulguları teknik olarak özetle tartışılmaktadır. Bu çalışmada, özellikle endüstriyel lif atıklarının farklı kullanım oranlarında hazırlanan harç örneklerinde 3 farklı lifin kullanım için uygunluğu incelenmekte olup, elde edilen bulgulara dayanılarak, karışımlarda kullanılan malzeme tür ve miktarlarının otoklavsız gazbeton blok elemanı örneklerinin teknik özelliklerine olan etkileri detaylı analiz edilmektedir. Yeni nesil yap1 elemanı örneklerinin birim ağırlık, dayanım, kütlece su emme, görünür gözeneklilik ve isısal konfor özellikleri gibi fiziksel ve mekanik özellikleri bu bildiride endüstriyel yaklaşımlarıyla tartışılmaktadır.

\section{Materyal ve Metot}

\subsection{Kullanılan Malzemeler}

Çalışma kapsamında, otoklavlanmamış gazbeton blokların üretiminde kullanılan malzemeler aşağıda özetle tanımlanmıştır:

\subsubsection{Cimento}

Otoklavlanmamış gazbeton numuneleri hazırlanırken, bağlayıcı işlevinin gerçekleştirilmesi amacıyla EN 197-1 CEM 1 42.5R (42.5 N/mm²) standardına uygun Portland çimentosu kullanılmıştır. Çimento malzemesi piyasadan temin edilerek kullanılmıştır.

\subsubsection{Kum}

Test numunelerinin hazırlanmasında $500 \mu \mathrm{m}$ elek altı boyutlandırılmış standart kum, tüm karışımlarda ana agrega malzeme olarak kullanılmıştır.

\subsubsection{Sönmemiş Kireç (CaO)}

Çalışma kapsamında, hazırlanan karışımların kimyasal reaksiyonu için ihtiyaç duyulması sebebiyle 250 mikron boyut altına sınıflandırılmış sönmemiş kireç kullanılmıştır. Kireç taşının pişirilmesi (kalsinasyonu) ile sönmemiş kireç oluşur $(\mathrm{CaO})$. Sönmemiş kirecin bağlayıcı malzeme olarak kullanılabilmesi için suyla birleştirilerek hidrate edilmesi gerekmektedir. Söndürme işlemi sırasında sönmemiş kireç suyla ekzotermik reaksiyona girer. Yarım kilo sönmemiş kireç, $0^{\circ} \mathrm{C}$ 'deki 1 litre suyun sıcaklığını $100^{\circ} \mathrm{C}^{\prime}$ ye çıkaracak büyüklükte bir reaksiyon 1sısı vermektedir. Isı ile birlikte hacmi 2,5 kat kadar artış gösterebilir. Sönmemiş kireç kullanımı, test örneklerinin kimyasal reaksiyonu sürecinde sönme işlevini gerçekleştiren kirecin açığa çıkardığı 1sı sayesinde karışımda yer alan alüminyum tozları ile reaksiyona girerek, hidrojen açığa çıkmasına ve gaz boşluklarının oluşmasına neden olmaktadır.

\subsubsection{Hava Sürükleyici Ajan (Alüminyum Tozu)}

Otoklavlanmamış gazbeton numunelerinin üretiminde \%99.9 saflık derecesinde nano boyutta alüminyum tozu genleştirici ana ajan materyali olarak ticari piyasadan tedarik edilerek kullanılmıştır. Örneklerin hidratasyonunda kimyasal reaksiyonu ile hidrojen gazı açı̆̆a çıkarak kabarcıkların oluşması ve matris yapının gözenekli bir form kazanmasını sağlamaktadır.

\subsubsection{Kimyasal Katkular}

Test örneklerinin daha hızlı priz almasını sağlamak ve daha gözenekli bir matris formu oluşturmak amacıyla karışımlarda doğal sodyum sülfat ve kalsiyum klorür katkı maddeleri kullanılmıştır. Doğal sodyum sülfat, toz formunda kullanılmıştır. Doğal sodyum sülfat, nötr bir tuz olup, kimyasal yöntemlerle üretilen ve yan ürün niteliğindeki sülfata kıyasla arsenik, kurşun, çinko, krom gibi ağır metaller ve hiçbir toksik minerali içermemektedir. Beyaz renkte, kristal yapıda ve serttir. Su ile kolaylıkla çözünebilmektedir. Priz süresini kısaltmak amacıyla harç karışımlarına bir diğer kimyasal katkı olarak kalsiyum klorür $\left(\mathrm{CaCl}_{2}\right)$ ilave edilmiştir. Bu katkı, kalsiyum ve klorun tuz formunda olup, oda sicaklığında beyaz ve katıdır. Suyla çözünerek bulunduğu ortamı 1sıtabilme özelliğine sahiptir.

\subsubsection{Lifler}

Çalışma kapsamında üç farklı özellikte doğal içerikli endüstriyel atık lif türü ticari piyasadan temin edilerek ve boyut ayarlaması yapılarak kullanılmıştır. Bu liflerden iki türü, kot kumaşının geri dönüşümünde kot elyaf açma işleminden geçirilerek elde edilmiş elyaf malzemesinden oluşmaktadır. Çalışma kapsamında "Lif 1" türü olarak kodlanmış elyaf türü 90/10 pamuk/sentetik oranına sahip olup, maksimum lif boyutu 3 mm'dir (Şekil 1). "Lif 2" türü olarak kodlanmış elyaf türünde ise pamuk oranı 1. lif türüne göre daha düşük olup, 70/30 pamuk/sentetik oranına sahiptir. Ayrıca bu lif malzemenin maksimum lif boyutu ise daha kısa olup 2 mm'dir (Şekil 2). Bu her iki kot kumaşının geri dönüşümünden elde edilmiş lif türleri doğal kumaş elyafları arasında değerlendirilebilecek özellikler taşımaktadır. Geri dönüştürülmüş tekstil elyaflarından elde edildikleri için çevre dostu malzemeler olarak da tanımlanabilir. Diğer lif türü ise "Lif 3" olarak kodlanmış olup, endüstriyel kâğıt atıklarının geri dönüşümünden elde edilmiş ve ortalama lif uzunluğu $\sim 200 \mu \mathrm{m}$ olan orta büyüklükte, \% 100 doğal, yüksek oranda saf selüloz beyaz renkli bir elyaftır (Şekil 3). Lif türlerinin her biri kompozit yapıda oluşturulan farklı harç kompozisyonlarında gerek doğal donatı amaçlı gerekse harcın 
işlenebilirliğinin artırılması, priz alma süreçlerinde olası büzülme ve çatlama olgularının minimize edilmesi için tercihen de kullanılan lif türlerdir.

\subsection{7. $\mathrm{Su}$}

Tüm test örneklerinin hazırlanmasında karma suyu olarak çeşme suyu kullanılmış olup, elektrikli bir ısıııcı yardımıyla $80^{\circ} \mathrm{C}$ 'ye kadar 1 sıtıılmış ve kimyasal reaksiyonun kısa sürede gerçekleşmesinin sağlanması amacıyla bu sıcaklık değerini koruyarak karışımlara dâhil edilmiştir.

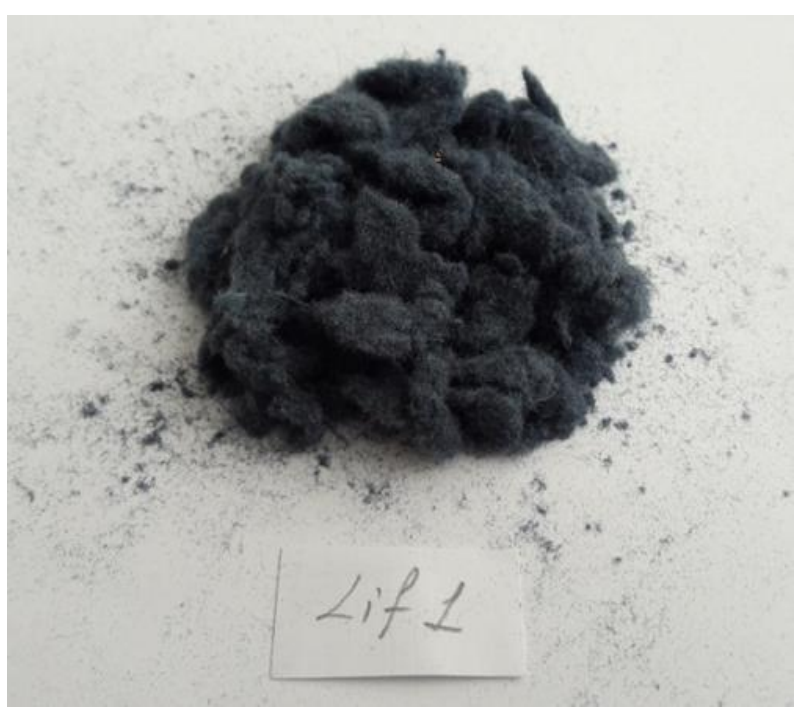

Şekil 1. Lif 1 malzemenin genel görünümü.

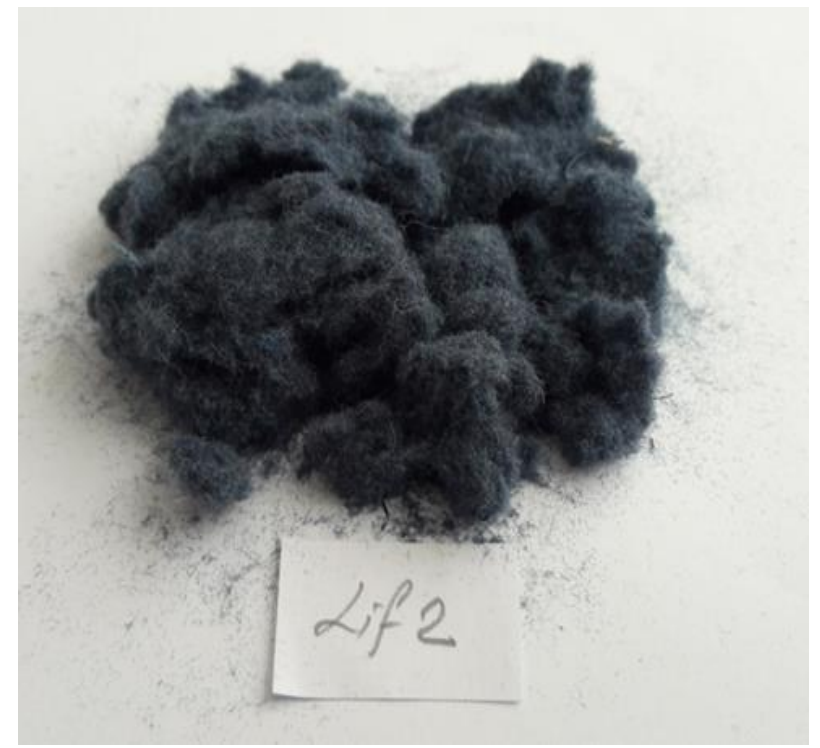

Şekil 2. Lif 2 malzemenin genel görünümü.

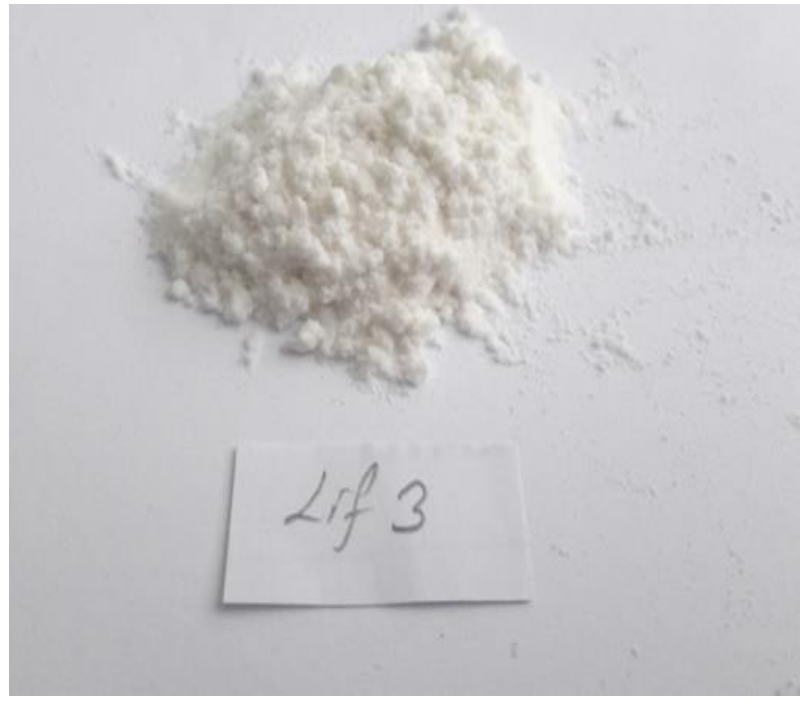

Şekil 3. Lif 3 malzemenin genel görünümü.

\subsection{Karıșım Tasarımı ve Testler}

$\mathrm{Bu}$ deneysel incelemede, endüstriyel atık liflerin kullanımıyla üretilen otoklavlanmamış gazbeton numuneler üzerindeki etkisini incelemek üzere farklı karışım oranları tasarlanmıștır. Ayrıca atık lif kullanımından kaynaklanabilecek etkileri daha reel bir şekilde irdeleyebilmek amacıyla, ayrı bir karışım formu olarak da kontrol karışımları tasarlanmıştır. Harç kombinasyonlarının tasarımı Çizelge 1'de verilmiştir.

Çizelge 1'den de görüleceği gibi MK1 ve MK2 kodlu karışımlar, otoklavlanmamış gazbeton numunelerin fiziksel ve mekanik özelliklerini karşılaş̧ırabilmek amacıyla, endüstriyel atık lifler kullanılmadan formülize edilmiş̧ir. MK1 karışım kombinasyonunda atık lif kullanımının kullanılmamasının yanı sıra ayrıca karışım bileşiminde sodyum sülfat kullanımı da yoktur. MK1 hariç diğer tüm karışım kombinasyonlarında sodyum sülfat katkı oranı ağırlıkça \%2 oranında sabit olarak uygulanmıştır. Deney örneklerinin hazırlanmasında MU1 ve MU2 kodlu karışımlarda Lif 1, Mí1 ve Mí2 kodlu karışımlarda Lif 2 türü ve MB1 ve MB2 kodlu karışımlarda ise Lif 3 türü kullanılmıştır. MU1, Mİ1 ve MB1 karışımlarında lif kullanım oranları ağırlıkça $\% 1,25$ ve MU2, Mi2 ve MB2 karışımlarında ise lif kullanım oranları ağırlıkça \%1,50 olarak uygulanmıştır. Böylece inceleme sürecinde her bir lif türü için 2 ayrı kullanım oranının etkilerinin karşılaştırılabilmesi hedeflenmiş̧ir. Lif kullanımı olan tüm karışımlarda lif miktarı, karışımdaki ana agrega bileşeni kum ile ağırlıkça yer değiştirmeli olarak tasarlanmıştır. Bununla birlikte, kontrol örnekleri de dahil olmak üzere tüm karışımlarında çimento oranı ağırlıkça $\% 34, \mathrm{CaO}$ oranı ağırlıķa $\% 9$, alüminyum tozu oranı ağırlıķ̧a $\% 0,1$ ve $\mathrm{CaCl}_{2}$ oranı da ağırlıkça \%1 oranlarında sabit değerler olarak uygulanmıştır. Karışımların kıvam ve form açısından daha sağlıklı karşılaştırılabilmesini sağlamak amacıyla tüm karışımların Su/Katı oranı da 0,65 olarak sabit tutulmuştur. 
Çizelge 1. Test örneklerinin hazırlanmasında kullanılan karışım oranları (Ă̆ırlıkça).

\begin{tabular}{|c|c|c|c|c|c|c|c|c|}
\hline Numune & $\begin{array}{c}\text { Çimento } \\
(\%)\end{array}$ & $\begin{array}{l}\text { Lif } \\
(\%)\end{array}$ & $\begin{array}{c}\text { Kum } \\
(\%)\end{array}$ & $\begin{array}{c}\mathrm{CaO} \\
(\%)\end{array}$ & $\begin{array}{c}\text { Al } \\
(\%)\end{array}$ & $\begin{array}{c}\mathrm{Na}_{2} \mathrm{SO}_{4} \\
(\%)\end{array}$ & $\begin{array}{c}\mathbf{C a C l}_{\mathbf{2}} \\
(\%)\end{array}$ & Su/Kat \\
\hline MK1 & 34 & 0 & 55,90 & 9 & 0,10 & 0 & 1 & 0,65 \\
\hline MK2 & 34 & 0 & 53,90 & 9 & 0,10 & 2 & 1 & 0,65 \\
\hline MU1 & 34 & 1,25 & 52,65 & 9 & 0,10 & 2 & 1 & 0,65 \\
\hline MU2 & 34 & 1,50 & 52,40 & 9 & 0,10 & 2 & 1 & 0,65 \\
\hline Mİ1 & 34 & 1,25 & 52,65 & 9 & 0,10 & 2 & 1 & 0,65 \\
\hline Miं2 & 34 & 1,50 & 52,40 & 9 & 0,10 & 2 & 1 & 0,65 \\
\hline MB1 & 34 & 1,25 & 52,65 & 9 & 0,10 & 2 & 1 & 0,65 \\
\hline MB2 & 34 & 1,50 & 52,40 & 9 & 0,10 & 2 & 1 & 0,65 \\
\hline
\end{tabular}

Tüm harç kombinasyonlarının karıştırma işleminde önce ana karışım bileşenleri olarak kum, çimento, $\mathrm{CaO}$ ve lif malzemeler öncelikli olarak karıştırılmış ve daha sonra kimyasal katkı olarak $\mathrm{Al}$, sodyum sülfat ve $\mathrm{CaCl}_{2}$, karma suyu ilavesiyle eş zamanlı olarak karışıma dâhil edilmiştir. Karma suyu olarak kullanılan suyun sıcaklığı tüm karışımlarda $80^{\circ} \mathrm{C}$ olarak sabit tutulmuş olup, karışıma su ilavesiyle birlikte 3 dakika süreyle karıştırma işlemi yapılmış, oluşan yaş harç formu hazırlanmış olan test örnek kalıplarına zaman gecikmesi olmaksızın dökümü sağlanmıştır. Kalıplanan yaş harçlar, sonrasında sıcaklığı önceden $60^{\circ} \mathrm{C}$ olarak ayarlanmış bir etüv ortamında minimum 6 saat süreyle ön kürleme işlemine tabi tutulmuştur. Sonrasında ise etüvden alınan örnekler 24 saat boyunca kapalı ve sıcaklığ1 minimum $+18^{\circ} \mathrm{C}$ olacak bir ortamda kürleme işlemine devam edilerek kalıplardan çıkartılmış ve normal oda koşullarında nihai kürlemeye bırakılmıştır. Tüm örneklerin kürlenmesinde herhangi bir otoklav kürleme işlemi yapılmamıştır.

Endüstriyel atık liflerin kullanımıla üretilen otoklavlanmamış gazbeton kâgir blok örneklerini temsil edebilmesi amacıyla, deneysel çalışmada 100x100x120 mm boyutlu dikdörtgen şekilli numunelerden her bir karışım için en az 15 adet numune dökümü yapılmıştır. Ayrıca 3 adet de levha şekilli örnek dökümleri de gerçekleştirilmiştir. Kalıplardan çıkartılan test örneklerinin 1, 3, 7, 14, 21 ve 28. günlerde özellikle kuruma ve sertleşme durumları gözlenmiş, bu sürelerde birim ağırlıklarındaki değişimler düzenli olarak tartılarak kaydedilmiştir. 28 gün kür sonrası her bir karışım kombinasyonunun birim hacim kütle, basınç dayanımı, su emme, gözeneklilik oranı ve 1sıl iletkenlik değerleri analiz edilmiştir. Numunelerin birim hacim ağırlık analizleri TS EN 1015-10 standardına uygun olarak tespit edilmiş olup, diğer fiziksel ve mekanik analizler TS EN 771-4 standardı ve ilgili standartların öngördüğü prensiplere göre uyarlanarak analiz edilmiştir.

\section{Araştırma Sonuçları ve Tartışma}

Çalışma kapsamında hazırlanan örnekler üzerinde yapılan test ve değerlendirmelerde elde edilen fiziksel ve mekanik özellikler, ortalama değerler olarak Çizelge 2'de özetlenmiştir.

\subsection{Mikroskobik Yapısal Analiz}

Mikroskobik analiz, malzemelerin veya ürünlerin mikro yapısını anlamak ve görsel olarak irdelemek için uygulanabilen bir yöntemdir. Mikroskobik analizlerden elde edilen veriler, yürütülmekte olan bir araştırma ve/veya ürün geliştirme programlarının daha da geliştirilebilmesi, matris yapıda etkin olan görsel parametrelerin tanımlanması vb. hususlar için önemlidir. Mikroskobik yapısal inceleme, özellikle matris yapının irdelenebilmesi, oluşan gözeneklilik durumu, karışım bileşenlerinde yer alan agrega veya donatı materyallerinin fiziksel şekilleri, matriste oluşturdukları formlar vb. gibi hususların incelenebilmesine olanak sağlamaktadır. Bu çalışma kapsamında hidrate olmuş ve sertleşmiş otoklavsız tüm gazbeton test örneklerinin mikroskobik analizleri yapılmış ve genel bulgular bazı karışım kombinasyonları için Şekil 4-Şekil 7'de sembolik olarak verilmiştir.

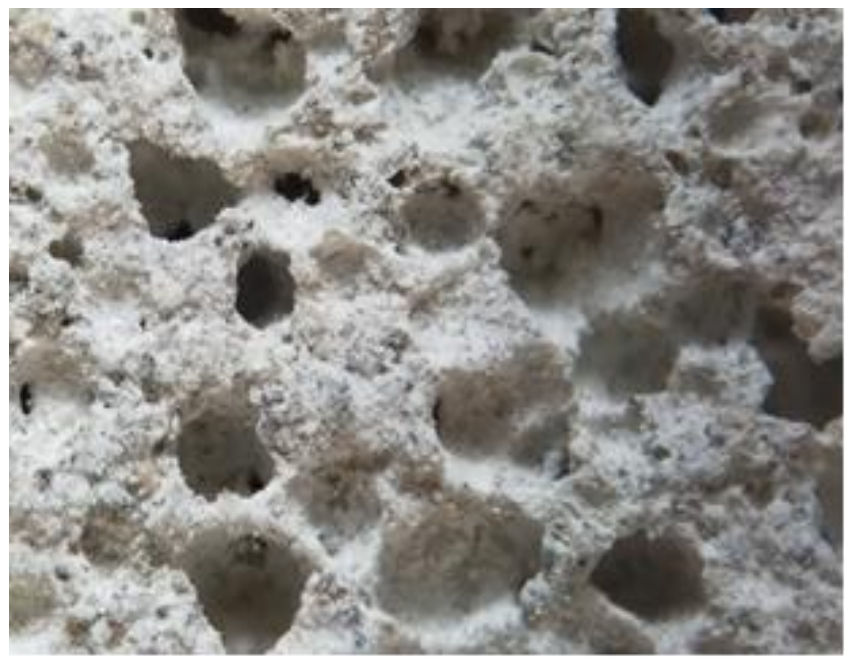

Şekil 4. MK2 örneğine ait genel yapısal görünümü. 


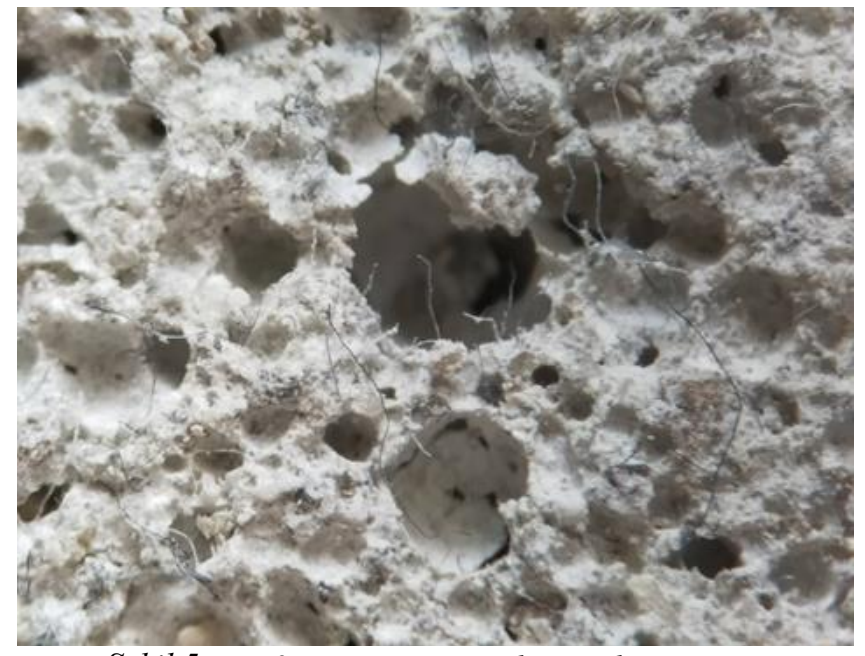

Şekil 5. MU2 örneğine ait genel yapısal görünümü.

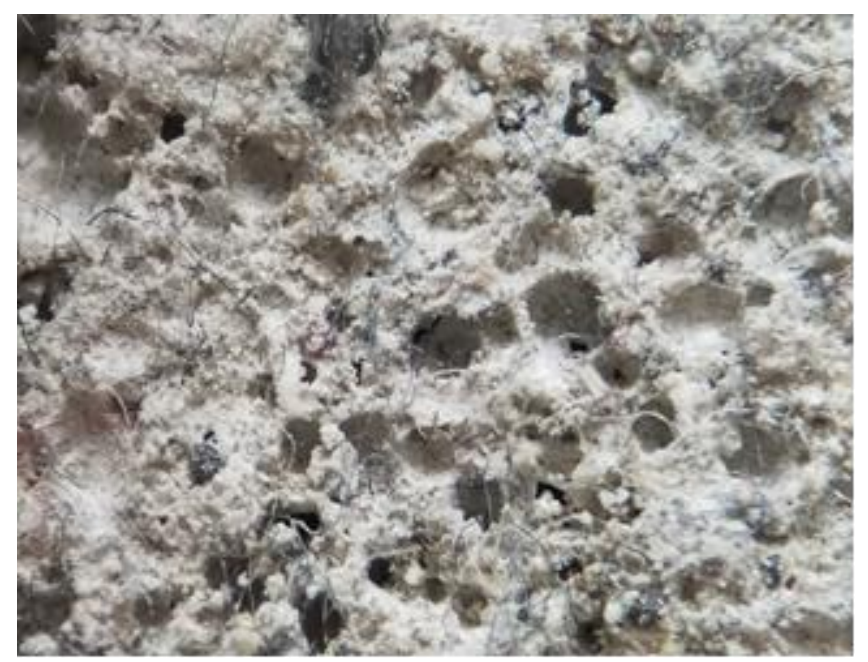

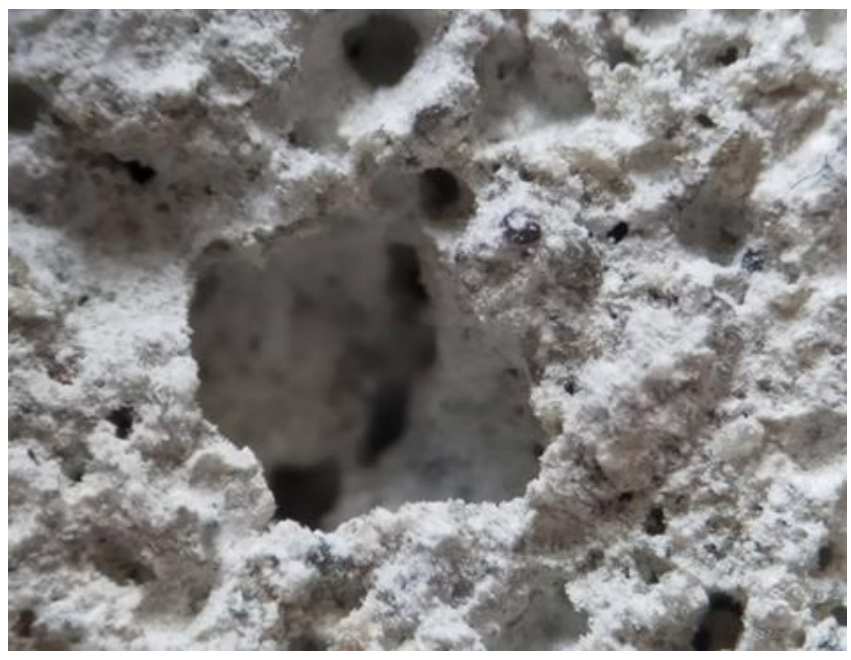

Şekil 7. MB2 örneğine ait genel yapısal görünümü.

Şekil 6. Mí2 örneğine ait genel yapısal görünümü.

Çizelge 2. Karışımlara ait bazı fiziksel ve mekanik özellikler.

\begin{tabular}{cccccc}
\hline Numune & $\begin{array}{c}\text { Birim Hacim } \\
\text { Ăgırlk } \\
\left(\mathrm{kg} / \mathrm{m}^{3}\right)\end{array}$ & $\begin{array}{c}\text { Kütlece Su } \\
\text { Emme } \\
(\%)\end{array}$ & $\begin{array}{c}\text { Basınç } \\
\text { Dayanımı } \\
\left(\mathrm{N} / \mathrm{mm}^{2}\right)\end{array}$ & $\begin{array}{c}\text { Görünür } \\
\text { Gözeneklilik } \\
(\%)\end{array}$ & $\begin{array}{c}\text { Isll } \\
\text { Illetkenlik } \\
(\mathrm{W} / \mathrm{mK})\end{array}$ \\
\hline MK1 & 979 & 41,90 & 1,46 & 49,12 & 0,288 \\
MK2 & 854 & 44,55 & 0,76 & 45,94 & 0,241 \\
MU1 & 781 & 47,82 & 1,70 & 46,61 & 0,205 \\
MU2 & 793 & 49,85 & 1,88 & 50,51 & 0,218 \\
Mİ1 & 749 & 45,80 & 1,28 & 44,60 & 0,214 \\
MI2 & 725 & 48,87 & 1,12 & 46,86 & 0,196 \\
MB1 & 852 & 44,85 & 1,44 & 47,97 & 0,234 \\
MB2 & 839 & 45,97 & 1,18 & 47,33 & 0,235 \\
\hline
\end{tabular}


Şekil 4 - Şekil 7'den görüleceği üzere, endüstriyel atık lif katkılarının matris yapıda saçınımlı olarak düzenli ve/veya düzensiz dağımlar sergileyebildiği görülmekle birlikte, karışım kombinasyonlarında oluşan kimyasal reaksiyonlar sonrası farklı gözeneklilik oranlarında boşluklu matris yapıların oluştuğu görülmektedir. Özellikle, endüstriyel kâğıt atıklarının geri dönüşümünden elde edilmiş doğal ve yüksek oranda saf selüloz içeren lif katkılı karışım kombinasyonlarına ait matris yapılarda, kot kumaşının geri dönüşümünde kot elyaf açma işleminden geçirilerek elde edilen lif türlerinin kullanıldığı matris yapılara göre daha düzensiz boşluklu harç matrislerinin oluştuğu gözlenmiştir. Bunun da daha zayıf dayanımlı matris yapıları oluşturduğu ve harcın mekanik özelliklerini olumsuz yönde etkileyebilecek bir durum olarak değerlendirilebilir.

\subsection{Birim Hacim Ăğırlık}

Birim hacim ağırlık değeri otoklavsız gazbeton kâgir blok elemanlarının irdelenmesinde önemli bir özelliktir. Özellikle, kâgir elemanın uygulama yerine uygunluğu açısından basınç dayanımının ve ayrıca ısıl iletkenlik performansının analizinde önem kazanmaktadır. Düşük birim hacim kütle değerine sahip kâgir blok elemanlarının genellikle basınç dayanım değerleri de düşük değerlerde olabilmekte ve bu tür kâgir elemanların taşıyıcı olmayan yapılarda kullanımları uygun olabilmektedir. Bununla birlikte birim hacim ağırlık değeri düşük olan kâgir blok elemanları ile örülen duvarların binaya olan ölü yük değerleri de düşük düzeylerde olup, özellikle binanın depremsellik açısından daha efektif duraylılığını da gündeme getirmektedir. Çalışma kapsamında özellikle herhangi bir lif ve sodyum sülfat katkısının kullanılmadığ 1 kontrol örneğinin ortalama kuru birim hacim ağırlık değeri $979 \mathrm{~kg} / \mathrm{m}^{3}$ iken, lif ilave edilmeksizin \%2'lik sodyum sülfat katkısı ile hazırlanan örneklerin ortalama kuru birim hacim ağırlık değeri \%12,7'lik hafifleme ile $854 \mathrm{~kg} / \mathrm{m}^{3}$ olduğu belirlenmiştir. Lif katkılarının kullanıldığı örneklerin ortalama kuru birim hacim ağırlık değerleri $725 \mathrm{~kg} / \mathrm{m}^{3}$ ile 852 $\mathrm{kg} / \mathrm{m}^{3}$ aralığında değişim gösterdiği görülmüştür. Tüm örneklerin kuru birim hacim ağırlık değerlerindeki değişim grafiksel olarak Şekil 8'de görülmektedir.

$\mathrm{Bu}$ analizden görüleceği üzere, lif katkılı örneklerin hazırlanmasında ana agrega bileşenleri, bağlayıcı ve kimyasal katkı oranları ve su/katı oranları eşdeğer özellikte olmasının yanı sıra, kullanılan lifin türü ve kullanım oranına bağlı olmak koşuluyla sertleşmiş blok örneği formlarının birim hacim ağırlık değerlerinin değişkenlik göstermesine sebep olmuştur. Lif 1 (90/10 pamuk/sentetik) türünün aynı karışım bileşenine sahip kontrol örneğine göre birim hacim ağırlığında düşme gözlenmiş olup, $\% 1,25$ lif oranında $\% 8,6$ ve $\% 1,5$ lif oranında ise $\% 7,1$ 'lik bir hafifleme olduğu tespit edilmiştir. Benzer şekilde Lif 2 (70/30 pamuk/sentetik) türü için $\% 1,25$ lif oranında $\% 12,3$ ve $\% 1,5$ lif kullanım oranında ise \%15,1'lik bir hafifleme olduğu tespit edilmiştir. $\mathrm{Bu}$ analizler göstermiştir ki, lif kullanım oranları aynı olmasına rağmen lif bileşiminin etkin olduğu ve özellikle lif bileşiminde pamuk oranının artmasına bağlı harcın daha fazla sıkışarak düşük oranda genleşmesine sebep olduğu görülmektedir. Ayrıca, Lif 3 türü doğal selüloz orijinli lif için ise kontrol örneğine göre bu değişim, \%1,25 lif oranında \%0,3 ve $\% 1,5$ lif oranında ise \%1,8'lik değişim oluşturduğu tespit edilmiştir. $\mathrm{Bu}$ tür lifin kâgir blok örneğinin kuru birim hacim ağırlık değişimine ihmal edilebilecek düzeyde bir etki ettiği görülmüştür.

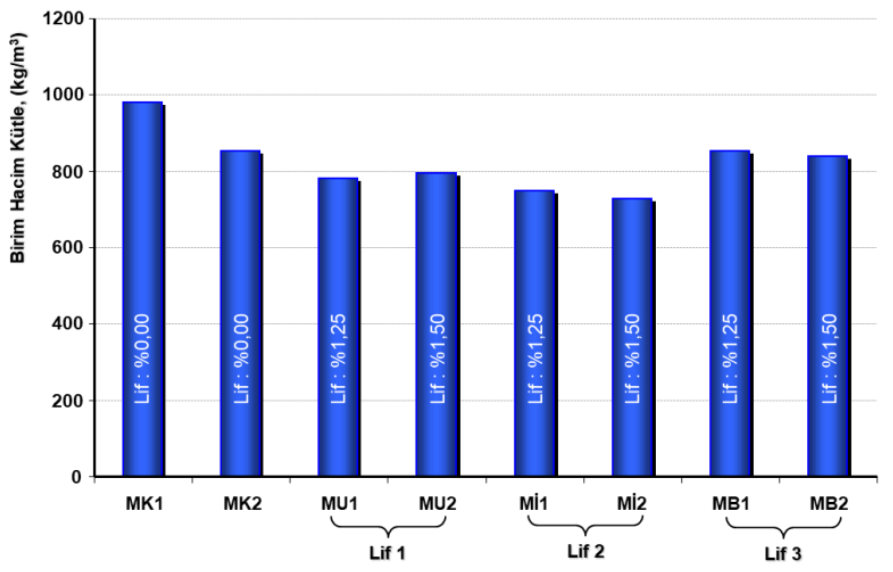

Şekil 8. Otoklavsız test örneklerinin kuru birim hacim ağırlık değerleri değişimi.

\subsection{Kütlece Su Emme}

Uygulama sonrası iç ve/veya dış yüzeyleri sıvasız olarak kullanılması düşünülen ya da yüksek oranda suya maruz kalabilecek ortamlarda kâgir bloklarla örülen duvarların kütlece su emme özellikleri, yapı elemanın nem barındırma ve buna bağlı olarak gelişebilecek bazı olumsuzlukların irdelenmesi açısından önem arz etmektedir. Örneğin, yüksek su emme değerine sahip olan yapı elemanlarının bünyelerinde tuttuğu nem ölçütüne göre 1sıl performanslarında önemli düşmeler söz konusu olabilmektedir. Bununla birlikte neme bağlı olarak yük taşıma kapasitesi özelliklerinde de zayıflamalar söz konusu olabilmektedir. Çalışma kapsamında kullanılan farklı lif türlerinin otoklavsız gazbeton kâgir blok elemanı test örneklerine olan etkileri incelenmiş olup, kütlece su emme değerleri Çizelge 2 ve grafiksel olarak da Şekil 9'da verilmiştir. $\mathrm{Bu}$ analizden görüleceği üzere, çalışma kapsamında herhangi bir lif ve sodyum sülfat katkısının kullanılmadığı kontrol örneğinin ortalama kütlece su emme değeri $\% 41,90$ iken, lif ilave edilmeksizin \%2'lik sodyum sülfat katkısı ile hazırlanan örneklerin ortalama kütlece su emme değeri \%6,3'lük bir artışla $\% 44,55$ olduğu belirlenmiştir. Bu su emme değerindeki artışın \%2'lik sodyum sülfat katkısı sebebiyle daha gözenekli bir matris yapı oluşmasının bir sonucu olduğu düşünülmektedir.

Çalışma kapsamında lif katkılı örneklerin kütlece su emme değerlerinin ortalama \%44,85 - \%49,85 aralığında değişim sergilediği belirlenmiştir. $\mathrm{Bu}$ analizlerde birim hacim ağırlık değişiminde gözlemlenen olguya benzer şekilde Lif 1 türünde pamuk oranının Lif 2'ye göre 20 birim daha fazla olmas1, örneklerin kütlece su emme özelliğinin daha yüksek değerlere ulaşmasına sebep olduğu gözlenmiştir. Lif 1 türünün aynı karışım bileşenine sahip kontrol örneğine göre kütlece su emme özelliğinde artış olduğu gözlenmiş olup, \%1,25 lif oranında $\% 7,35$ ve \%1,5 lif oranında ise \%11,9'luk bir su emme artış eğilimi olduğu tespit edilmiştir. Bu değerin artışındaki diğer bir etken faktörün, lifin ortalama uzunluğu ile doğrudan ilgili olduğu da tecrübe edinilmiştir. Malzeme karakteristiği açısından su tutma eğilimi yüksek liflerin aynı zamanda daha uzun boylarda kullanımı, harç matrisinin daha yüksek su tutma kapasitesi oluşturmasına ve dolaysıyla su emme değerinin yükselmesine sebep olabilmektedir. 


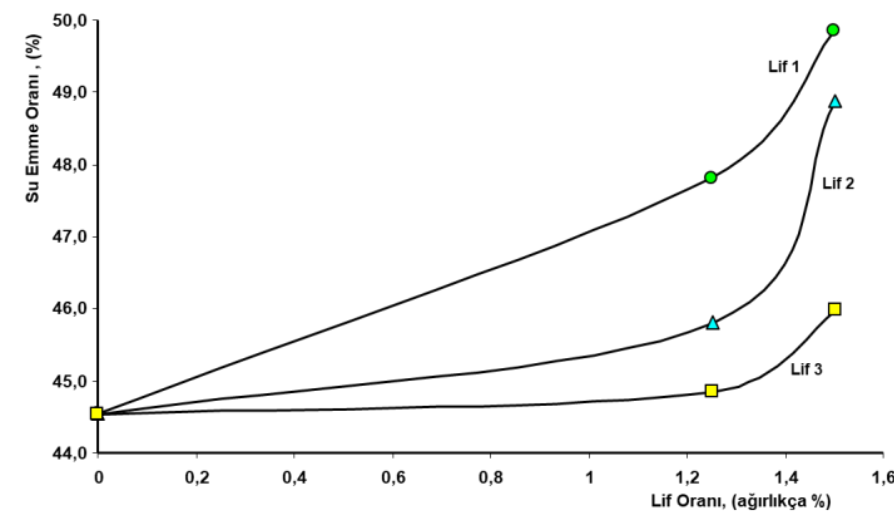

Şekil 9. Lif kullanım oranı ve kütlece su emme değerleri analizi.

Benzer şekilde Lif 2 (70/30 pamuk/sentetik) türü için \%1,25 lif oranında $\% 2,8$ ve $\% 1,5$ lif oranında ise $\% 9,7$ 'lik bir su emme özelliğinde artış eğilimi olduğu tespit edilmiştir. Buradan görüleceği gibi, endüstriyel atık lif bileşiminde sentetik oranı arttıkça, lif kullanım oranına da bağlı olmak koşuluyla su emme değerlerinde bir düşüş söz konusu olmuştur. Bu bağlamda, düşük su emme değeri arzu edilen örneklerin elde edilmesinde, sentetik oranı yüksek ve daha kısa lif boyutuna sahip lif kullanımının önemli olduğu görülmektedir. Doğal selüloz orijinli ve sentetik madde içermeyen Lif 3 türü ile yapılan örneklerde ise kontrol örneğine göre $\% 1,25$ lif oranında $\% 0,7$ ve $\% 1,5$ lif oranında ise \%3,2'lik bir su emme oranlarında artış eğilimi olduğu tespit edilmiştir. Diğer bir deyişle, doğal selüloz içerikli endüstriyel lif atıklarının boyutunun küçük olması ve bileşimine de bağlı olarak pamuk/sentetik bileşenli liflere göre daha düşük su emme olgulu örneklerin elde edilmesine olanak sağladığı görülmektedir. Ayrıca genel bir olgu olarak, matris yapıda yer alan pamuk bileşenli ve/veya doğal selüloz orijinli lif kullanımlarında, lif boyu arttıkça matris yapıda daha yüksek oranda su tutan birimlerin oluşmasına sebep olduğu tecrübe edinilmiştir.

\subsection{Basınç Dayanımı}

Basınç dayanım özelliği, kâgir blok elemanlarının uygulama yerinde ne büyüklükte bir taşıma yükü sağlayabileceğinin ölçütü olması bakımından önemli bir mekanik parametredir. Genel bir olgu olarak, çoğu inceleme çalışmalarında bir harcın mekanik dayanımının artırılması amacıyla bünyesine yerleştirilen donatı bileşenlerinin önemli bir etkisi olduğu tecrübe edinilmiştir. Bu bağlamda, harcın mekanik dayanım değerinin artırılması için ne oranda, hangi boyutlarda ve hangi orijinlerde donatı olarak da değerlendirilebilecek materyallerin karışım bünyesine ilave edilmesi gerektiği detay bir inceleme gerektiren husustur. $\mathrm{Bu}$ çalışma kapsamında 3 ayrı lif türünün 2 farklı kullanım oranında uygulanmasıyla elde edilen otoklavsız gazbeton örneklerinin 28 günlük kür sonrası mekanik dayanım değerlerine olan etkileri kontrol numuneleri ile kıyaslamalı olarak irdelenmiştir. Genel bulgular ortalama değerler olarak Çizelge 2 ve grafiksel olarak da Şekil 10'da verilmiştir.

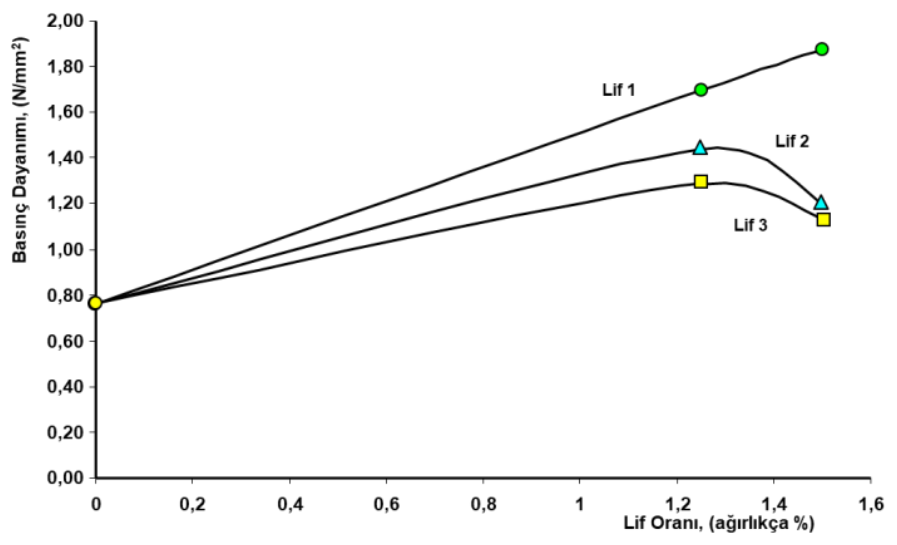

Şekil 10. Lif kullanım oranı ve 28 gün kür sonrası basınç dayanım değerleri analizi.

$\mathrm{Bu}$ analizden görüleceği üzere, çalışma kapsamında herhangi bir lif ve sodyum sülfat katkısının kullanılmadığı kontrol örneğinin 28 gün kür sonrası basınç dayanım değeri 1,46 $\mathrm{N} / \mathrm{mm}^{2}$ iken, lif ilave edilmeksizin sadece $\% 2$ 'lik sodyum sülfat katkısı ile hazırlanan örneklerin ortalama basınç dayanım değeri $\% 47,8$ 'lik bir düşüşle $0,76 \mathrm{~N} / \mathrm{mm}^{2}$ olduğu belirlenmiştir. $\mathrm{Bu}$ basınç dayanım değerindeki önemli düşüşün \%2'lik sodyum sülfat katkısı sebebiyle daha gözenekli bir matris ve daha zayıf bir bağ dokusu oluşmasının sonucu olduğu düşünülmektedir. Çalışma kapsamında lif katkılı örneklerin basınç dayanım değerlerinin ortalama $1,12 \mathrm{~N} / \mathrm{mm}^{2}-1,88 \mathrm{~N} / \mathrm{mm}^{2}$ aralı̆̆ında değişim sergilediği belirlenmiştir. Çalışmada kullanılan her üç lif türünden kontrol örneğinin basınç dayanım değerine göre beklenildiği gibi önemli ölçütlerde iyileştirme olguları gösterdiği tespit edilmiş olup, lif bileşimi ve kullanım oranının harç matrisinde oluşturduğu donatı ve kompaktlık özelliği sayesinde tüm lif kullanımlarında dayanım artışlarına sebep olduğu görülmüştür. Özellikle Lif 1 türünün kullanımında aynı karışım bileşenine sahip kontrol örneğine göre basınç dayanım değerinde $\% 1,25$ lif oranında 2,23 kat ve \%1,5 lif oranında ise 2,47 kat dayanım iyileşmesi tespit edilmiştir. Ayrıca, bu lif türü için elde edilen örneklerde lif kullanım oranındaki \%0,25'lik bir artışın dayanımda \%10,5'luk bir iyileşmeye neden olduğu görülmektedir. $\mathrm{Bu}$ lif türünde $90 / 10$ pamuk/sentetik oranında yüksek pamuk bileşenli ve $3 \mathrm{~mm}$ 'lik lif boyutu ile örneklerin matris yapısında daha yüksek sarmal bir lif olgusu ve daha kompakt form oluşturduğu gözlenmiş olup, bu durumun dayanım değerlerinde daha rasyonel bir iyileşmeye neden olduğu tecrübe edinilmiştir. Diğer taraftan Lif 2 türünde ise, 70/30 oranlı daha düşük oranda pamuk bileşene sahip ve $2 \mathrm{~mm}$ 'lik lif boyutları ile daha kısa formdaki lif varlığında, kontrol örneğine göre basınç dayanım değerinde \%1,25 lif oranında 1,68 kat ve $\% 1,5$ lif oranında ise 1,48 kat dayanım iyileşmesi tespit edilmiştir. Bu iyileşme miktarları, daha düşük oranda pamuk ve görece kısa lif varlığının doğal bir sonucu olarak tecrübe edinilmiştir. Ancak, bu lif türü için örneklerin hazırlanmasında $\% 0,25$ 'lik bir lif kullanım oranı (\%1,25'den \%1,50’ye çıkartılması) artışının dayanımda \%12,3'lük bir düşmeye neden olduğu görülmüştür. Görece daha kısa boyutlu lif kullanım oranı, yüksek miktarlarda kullanımlarda yeterli düzeyde dayanım açısından donatı görevi oluşturamadığı gözlenmiştir. Bu bağlamda, lif kullanımı için optimum değerin tespiti daha önemli olmaktadır. $\mathrm{Bu}$ optimum değerin Lif 2 türü için bu çalışma kapsamında uygulanan karışım kombinasyonunda ağırlıkça \%1,33'lük bir kullanım oranına denk geldiği istatistiksel 
analizden elde edilmiştir. Doğal orijinli selüloz lif (Lif 3) kullanımıyla elde edilen örneklerin kontrol örneğine göre basınç dayanım değerlerinde ise \%1,25 lif oranında 1,89 kat ve \%1,5 lif oranında ise 1,55 kat dayanım iyileşmesi olduğu tespit edilmiştir. Ayrıca, bu lif türü için örneklerin bileşiminde yer alan \%0,25'lik bir lif kullanım artışının dayanımda \%17,8'lik bir zayıflamaya neden olduğu görülmüştür. Lif 2 türünde olduğuna benzer şekilde, görece daha kısa boyutlu lif kullanım oranının artması, nihai basınç dayanımlarında da bir düşüşe sebep olduğu tecrübe edilmiştir. Genel bir olgu olarak, lif katkılı tüm örneklerin dayanım değerlerinin eşdeğer karışımlı kontrol örneklerinin değerlerinden daha yüksek olduğu görülmüştür. Elde edilen bu bulgular bağlamında, normal harçlarda tecrübe edinilen hususlara kıyasla, genleşme yoluyla elde edilmiş ve otoklavlanmamış hafif beton kâgir birimlerde, kısa boyutlu lif kullanımlarının beklenildiği düzeyde basınç dayanım artışlarına yeterli cevap veremediği gözlenmiştir. Ancak, karışım bileşenlerine yeni ilave edilebilecek farklı tür katkılar ile matris yapının kuvvetlendirilmesiyle bu olgu beklenilen düzeylere ulaştırılabilir. Bu çalışmada lif katkılı örnekler için elde edilen basınç dayanım değerlerinin, taşıyıcı olmayan özelliklerde ve dolgu/yalıtım amaçlı kâgir birimlerin üretilmesine imkân tanıyabilecek özellikler taşıdığı görülmektedir.

\subsection{Görünür Gözeneklilik}

Gözeneklilik, gözenek boşluğunun hacmi ile numunenin toplam hacmi arasındaki yüzde ilişkisi olarak tanımlanabilmektedir. Gözeneklilik, sertleşmiş harç formundaki yapı elemanlarının birim ağırlık değerleri, ısıl performans etkilerinin incelenmesi ve dayanım değerlerinin analizi gibi hususlarda önem arz eden parametreler arasında yer almaktadır. Genellikle yüksek gözenekliliğe sahip malzeme yapılarında özellikle kapalı gözenek olgularının yüksek olması, bünyelerinde hapsolmuş durağan hava varlığının bir ölçütünü temsil etmekte ve 1s1l performans değerlerinin göreceli olarak yüksek ve birim ağırlıklarının da düşük olmasına olanak sağlamaktadır. Görünür gözeneklilik, bir numunedeki yığın dokusunun numunenin yı ̆̆ın hacmine oranı olarak tanımlanabilir. Bu çalışmada, numunelerin görünen gözeneklilik oranı, birim hacim ağırlık ve su emme değerinin bir fonksiyonu olarak tanımlanarak belirlenmiștir. Görünür gözeneklilik aşağıdaki eşitlik kullanılarak hesaplanmıştır:

$$
P_{1}=\frac{W_{f}^{*} \rho_{t}}{\rho_{w}}
$$

Burada;

$\mathrm{P}_{1}$ : Görünür gözeneklilik (\%),

$\mathrm{W}_{\mathrm{f}}$ : Kütlece Su Emme (\%),

$\rho_{\mathrm{t}} \quad$ : Kuru birim hacim a ğırlı $\mathrm{k}\left(\mathrm{kg} / \mathrm{m}^{3}\right)$,

$\rho_{\mathrm{w}}$ : Suyun yoğunluğu $\left(\mathrm{kg} / \mathrm{m}^{3}\right)$

Bu çalışma kapsamında 3 ayrı lif türünün 2 farklı kullanım oranında uygulanmasıyla elde edilen otoklavsiz gazbeton örneklerinin 28 günlük kür sonrası görünür gözeneklilik oran değerlerine olan etkileri kontrol numuneleri ile karşılaştırılarak irdelenmiştir. Genel bulgular ortalama değerler olarak Çizelge 2 ve grafiksel olarak da Şekil 11'de verilmiştir.

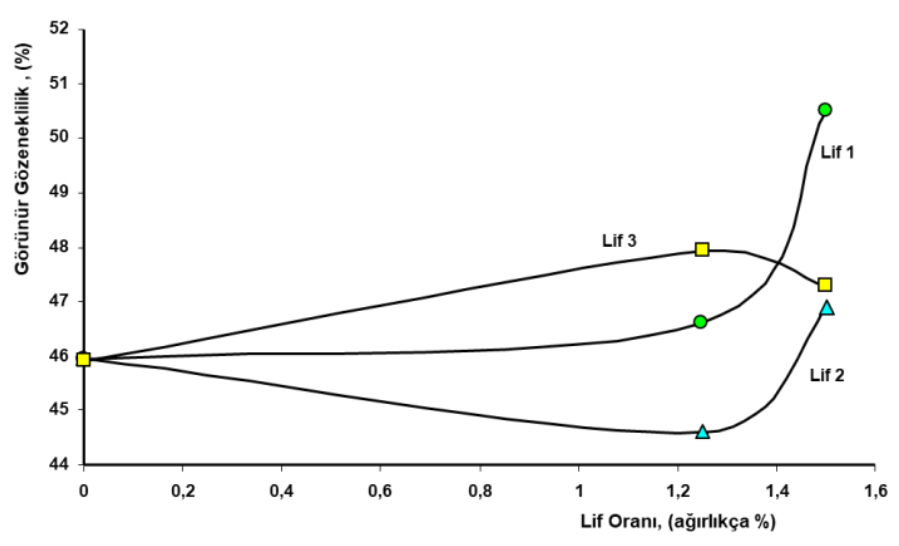

Şekil 11. Lif kullanım oranı ve 28 gün kür sonrası görünür gözeneklilik oran değerleri analizi.

Lif ve sodyum sülfat katkısı kullanılmadan elde edilen kontrol örneğinin 28 gün kür sonrası ortalama görünür gözeneklilik oran değeri \%49,12 iken, lif ilave edilmeksizin yalnızca \%2'lik sodyum sülfat katkısı ile hazırlanan örneklerin ortalama görünür gözeneklilik değeri $\% 6,5$ 'lik bir düşüşle \%45,94 olduğu belirlenmiştir.

Lif 1 türünün kullanımında eşdeğer bileşime sahip kontrol örneğine göre görünür gözeneklilik değerinde $\% 1,25$ lif oranında $\% 1,46$ 'lık ve \%1,5 lif oranında ise \%9,96'lık bir artış olduğu tespit edilmiştir. Lif kullanım oranındaki artış, sertleşmiş kâgir örneğinin matris yapısında daha yüksek bir gözenekliliğin oluşmasına neden olmuştur. $\mathrm{Bu}$ olgu, lif bileşimindeki pamuk oranının yüksekliğine bağlı olarak liflerin matriste daha saçınımlı bir formda yer alması ve lif boyunun da görece uzun olması sebebiyle daha fazla boşluk oluşumlarının meydana gelmesini mümkün k1lmaktadır. Diğer taraftan, Lif 1'e göre daha kısa boyutta ve daha az oranda pamuk ihtiva eden Lif 2 türü için irdelendiğinde, kontrol örneğine göre görünür gözeneklilik değerinin $\% 1,25$ lif oranında $\% 2,92$ 'lik bir düşüş, ancak \%1,5 lif oranında ise \%2,02'lik bir artış sergilediği tespit edilmiştir. Burada, lif oranlarındaki kullanıma bağlı düşme veya artışın lif boyutu ile doğru orantılı olarak gelişim gösterdiği tecrübe edinilmiştir. Diğer bir değişle, lif boyutlarının kısalması, matris yapıda karıştırma, kalıba yerleştirme ve özellikle de genleşme özelliği ile elde edilen gazbeton türü matris yapılarda düzensiz formda dağılımlara ve dolayısıyla daha farklı olgularda gözenek oluşumlarına neden olabilmektedir. Benzer bir durum, bu çalışmada Lif 3 türü için de gözlenmiştir. Lif 3 türü kullanımında, kontrol örneğine göre görünür gözeneklilik değerinde $\% 1,25$ lif oranında $\% 4,44$ ve $\% 1,5$ lif oranında ise \%3,04'lük bir artış olduğu tespit edilmiştir.

\subsection{Isıl İletkenlik Özelliği}

Gözenekli matris yapılarına sahip kâgir elemanların en önemli özelliklerinden biri de gözenekliliğinin bir fonksiyonu olarak düşük yoğunluk değerlerinde sağladıkları 1sıl yalıtım performans özelliğidir. Malzemelerin 1sıl iletkenlik değeri $(\lambda)$ genellikle birim ağırlı̆̆ın bir fonksiyonu olarak değişir. Genel olarak, birim hacim ağırlığı arttıkça termal iletkenlik değerinin artma eğiliminde olması beklenir. Bu ayrıca malzemenin isısal konfor özelliğinin düştüğü ve daha zayıf bir performans değeri sergilediği anlamını da taşıyabilir. $\mathrm{Bu}$ sebeple, düşük 1Sı iletkenlik değerine sahip kâgir elemanların, kullanıldıkları yapı 
kesitlerinin daha yüksek enerji verimli yapıların oluşmasına sebep olabilmektedir. Sertleştirilmiş otoklavsız tüm gazbeton örneklerinin 28 günlük kür süresinden sonra 1sıl iletkenlik değerleri belirlenmiş olup, genel bulgular ortalama değerler olarak Çizelge 2'de verilmiştir. Ayrıca, test örneklerinin birim hacim ağırlık değişimlerine bağlı 1sıl iletkenlik değerleri arasındaki ilişki ise grafiksel olarak da Şekil 12'de analiz edilmiştir.

Şekil 12 irdelendiğinde görüldüğü üzere, gazbeton örneklerin beklenildiği gibi birim hacim ağırlık değerleri ile 1sıl iletkenlik değerleri arasında lineer kabul edilebilecek istatistiksel bir ilişki söz konudur. Birim hacim ağırlık değerlerinin azalmasına paralel olarak, isıl iletkenlik değerlerinde de düşme ve dolayısıyla daha enerji verimli bir form kazandıkları görülmektedir. Lif ve sodyum sülfat katkısı kullanılmadan elde edilen kontrol örneğinin 28 gün kür sonrası ortalama 1sıl iletkenlik değeri $0,288 \mathrm{~W} / \mathrm{mK}$ iken, lif ilave edilmeksizin yalnızca \%2'lik sodyum sülfat katkısı ile hazırlanan örneklerin ortalama 1 sıl iletkenlik değeri ise $0,241 \mathrm{~W} / \mathrm{mK}$ olduğu belirlenmiştir.

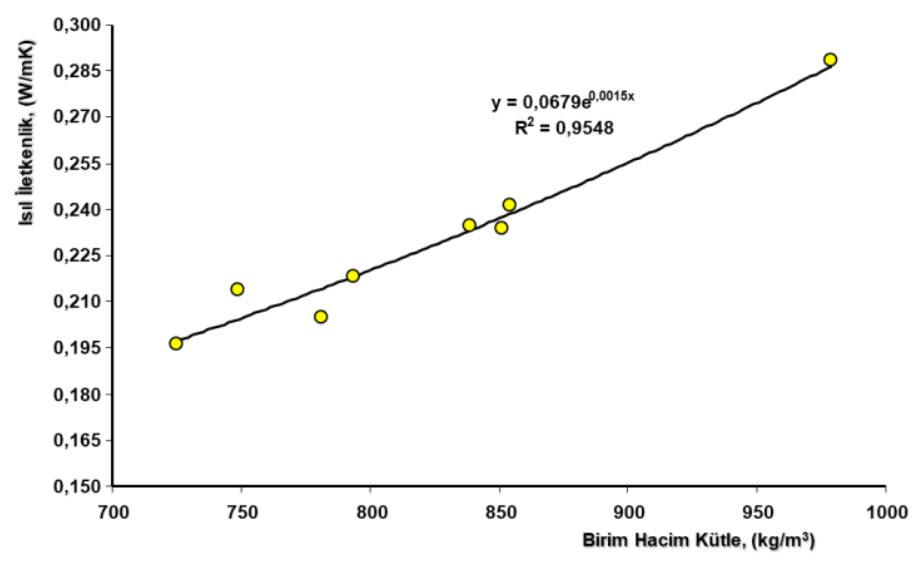

Şekil 12. Birim hacim ă̆ırlık ve ısıl iletkenlik değerleri ilişkisi.

Lif 1 türünün kullanımında aynı karışım bileşenine sahip kontrol örneğine göre 1sıl iletkenlik değerinde $\% 1,25$ lif oranında $\% 15^{\prime}$ lik ve $\% 1,5$ lif oranında ise $\% 9,5^{\prime} l 1 \mathrm{k}$ bir düşme olduğu tespit edilmiştir. Bu lif türü kullanımında artan lif oranının, ısısal performans değerinin zayıflamasına sebep olduğu tecrübe edinilmiştir. Diğer taraftan, Lif 2 türünün kullanımında ise bu olgunun tersine bir durum gözlenmiş olup, aynı karışım bileşenine sahip kontrol örneğine göre 1sıl iletkenlik değerinde $\% 1,25$ lif oranında $\% 11,3$ 'lük ve $\% 1,5$ lif oranında ise $\% 18,7^{\prime}$ lik bir düşme olduğu tespit edilmiştir. $\mathrm{Bu}$ lif türünde artan lif oranının, 1sısal performans değerinin iyileşmesine sebep olduğu görülmektedir. Lif 1 türüne benzer şekilde Lif 3 türü ile yapılan otoklavsız gazbeton örneklerinin aynı karışım bileşenine sahip kontrol örneğine göre 1sıl iletkenlik değerinde $\% 1,25$ lif oranında $\% 3$ 'lük ve \%1,5 lif oranında ise \%2,7'lik bir marjinal bir düşme oranı sergilediği tespit edilmiştir. Tüm bu değerlendirmeler grafiksel bir gösterimle Şekil 13'de verilmiştir.

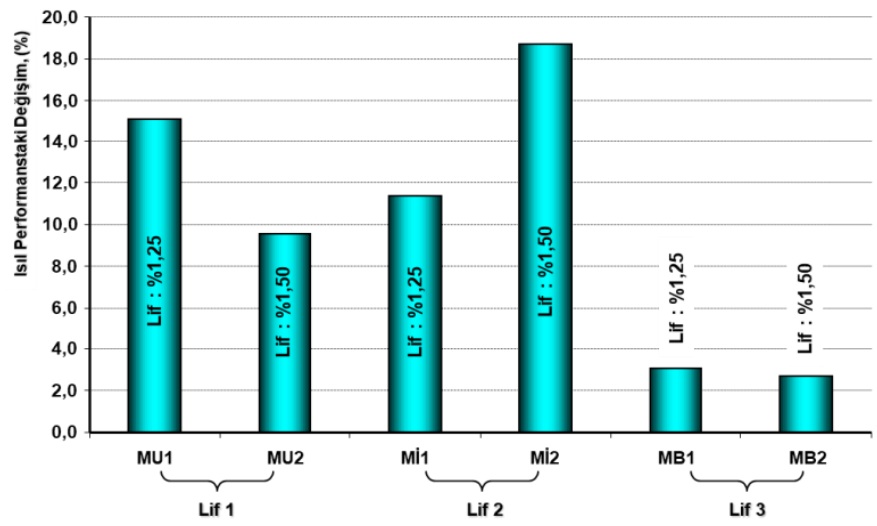

Şekil 13. Lif türleri - ısısal performans değişim analizi.

$\mathrm{Bu}$ grafiksel gösterim irdelendiğinde görüleceği üzere, binalarda enerji verimliliğine katma değer sağlayacak otoklavsız gazbeton ürünlerinin elde edilmesinde endüstriyel lif atıkları kullanımı söz konusu olduğu durumda, bu çalışmada edinilen tecrübe bağlamında öncelik sırasıyla Lif 2 , Lif 1 ve Lif 3 türlerinin kullanımlarının irdelenebileceği görülmüştür.

\section{Sonuçlar}

$\mathrm{Bu}$ çalışmada, özellikle taşıyıcı özellikte olmayan kâgir duvar elemanı kullanımlarında otoklavsı gazbeton üretimlerinde endüstriyel lif atıklarından 3 farklı tür malzemenin kullanım durumu ve kâgir elemanın teknik özelliklerine olan etkileri üzerinde değerlendirmeler yapılmıştır. Elde edilen bulgular bağlamında, genel olarak kot kumaşının geri dönüşümünde kot elyaf açma işleminden geçirilerek elde edilmiş elyaf malzemesinden oluşan liflerin, endüstriyel kâğıt atıklarının geri dönüşümünden elde edilmiş doğal ve yüksek oranda saf selüloz içeren liflere göre daha rasyonel sonuçlar oluşturduğu görülmüştür. Bununla birlikte, kot kumaşının geri dönüşümünden elde edilen lif türlerinde pamuk/sentetik oranının ve ayrıca lif uzunluğunun önemli bir etken parametre olduğu tespit edilmiş olup, mukavemet, gözeneklilik ve enerji verimlilik özelliklerinde iyileştirmelerin arzu edildiği durumlarda kot kumaşı lif türevlerinin bileşiminde pamuk oranının daha yüksek olması gerektiği tecrübe edinilmiştir. Ancak, lif bileşiminde yüksek pamuk oranı varlığı ve uzun lif boyunun, örneklerin su emme kabiliyetlerini artırdığı sonucuna varılmıştır. Düşük yoğunluk değerli örneklerin elde edilmesinde kot kumaşının geri dönüşümünden elde edilmiş liflerin, endüstriyel kâğıt atıklarının geri dönüşümünden elde edilmiş doğal ve yüksek oranda saf selüloz içeren liflere göre teknik kullanılabilirlik kriterlerinin daha yüksek olduğu görülmüştür. Bu çalışmada elde edilen test örneklerinin birim hacim kütle, basınç dayanım ve gözeneklilik vb. gibi teknik değerleri, karışımda yer alan agrega - katkı malzeme türleri ve kullanım oranlarının değişimi ve/veya ilave alternatif malzemelerin kullanımları ile yapılabilecek yeni araştırma çalışmalarında daha ergonomik sonuçlar sağlanabilir. Diğer bir deyişle, bu çalışmada elde edilen bulgulara kıyasla birim hacim ağırlık değerleri daha düşük, bunun yanı sıra gözeneklilik, ısıl performans ve basınç dayanım değerleri daha yüksek bulgular da elde edilebilir. 


\section{Teşekkür}

$\mathrm{Bu}$ çalışmanın her aşamasında laboratuvar imkânlarından yararlanma firsatı sunan İzmir Kâtip Çelebi Üniversitesi - İnşaat Mühendisliği Bölümüne şükranlarımı sunarım.

\section{Kaynakça}

Babu, D.S. (2008). Mechanical and deformational properties, and shrinkage cracking behavior of lightweight concretes. $\mathrm{PhD}$ thesis. national university of Singapore.

Bakhshi, M., Mobasher, B. (2011). Experimental observations of early-age drying of Portland cement paste under lowpressure conditions. Cement and Concrete Composites, 33(4),

474-484. doi:http://dx.doi.org/10.1016/j.cemconcomp.2011.01.009

Bonakdar, A., Babbitt, F., Mobasher, B. (2013). Physical and mechanical characterization of Fiber-Reinforced Aerated Concrete (FRAC), Cement \& Concrete Composites, 38, 8291.

doi:http://dx.doi.org/10.1016/j.cemconcomp.2013.03.006

Chen, Y-L., Chang, J-E., Lai, Y-C. and Chou, M-I. M. (2017). A comprehensive study on the production of autoclaved aerated concrete: Effects of silica-lime-cement composition and autoclaving conditions. Construction and Building Materials, 153, 622-629. doi:http://dx.doi.org/10.1016/j.conbuildmat.2017.07.116

El Zareef, M.A. (2010). Conceptual and structural design of buildings made of lightweight and infra lightweight concrete. $\mathrm{PhD}$ thesis. Deutschen natıonal bıblıothek.

Mobasher, B., Li, C.Y. (1996). Mechanical properties of hybrid cement-based composites. Materials Journal, 93(3), 284292.

Perez-Pena, M., Mobasher, B. (1994). Mechanical properties of fiber reinforced lightweight concrete composites. Cement and Concrete Research, 24(6), 1121-1132. doi:http://dx.doi.org/10.1016/0008-8846(94)90036-1

Rasheed, M.A., Prakash, S.S. (2017). Behavior of HybridSynthetic Fiber Reinforced Cellular Lightweight Concrete under Uni-axial Tension - Experimental and Analytical 20 Studies. Construction and Building Materials, 162, 857-870. doi:http://dx.doi.org/10.1016/j.conbuildmat.2017.12.095

Rasheed, M.A., Prakash, S.S. (2015). Mechanical Behavior Of Sustainable Hybrid-Synthetic Fiber Reinforced Cellular Light Weight Concrete For Structural Applications Of Masonry. Construction and Building Materials, 98, 631640.

doi:http://dx.doi.org/10.1016/j.conbuildmat.2015.08.137

Ronald, F., Carol, D.H. (1998). Engineering material properties of a fiber reinforced cellular concrete. Materials Journal, 95(5), 631-635.

Sanytsky M.A., (2010), Modified composite cements: A tutorial/ M.A. Sanytsky, H.S. Sobol, T.E. Markiv. - Lviv: Lviv Polytechnic Publishing House, 132 p.

Spratt, B.H. (1975). An introduction to lightweight concrete (5. bs.):Cement and Concrete Association.
Sukmana, N.C., Khifdillah, M.I., Nurkholil, A.S., Anggarini, U. (2019). Optimization Of Non-Autoclaved Aerated Concrete Using Phosphogypsum Of İndustrial Waste Based On The Taguchi Method. 13th Joint Conference on Chemistry (13th JCC) IOP Conf. Series: Materials Science and Engineering, 509, $\quad 012095 . \quad$ doi:https://doi.org/10.1088/1757$899 X / 509 / 1 / 012095$

Tanacan L., Ersoy H., Arpacipğlu U. (2009). Effect of high temperature and cooling conditions on aerated concrete proerties. Construction and Building Materials, 23(3), 12401248. doi:http://dx.doi.org/10.1016/j.conbuildmat.2008.08.007

Vijayalakshmi, R., Ramanagopal, S. (2020a). Compression behaviour of polypropylene fibre reinforced cellular light weight concrete masonry prism. Civil And Environmental Engineering Reports, 30(1), 145-160. doi:http://dx.doi.org/10.2478/ceer-2020-0011

Vijayalakshmi, R., Ramanagopal, S. (2020b). Experimental investigation into banana fibre reinforced lightweight concrete masonry prism sandwiched with GFRP sheet. Civil and Environmental Engineering Reports, 30(2), 15-31. doi:http://dx.doi.org/10.2478/ceer-2020-0017 